\title{
The Effect of Corporate Social Responsibility, Firm Size, and Leverage on Tax Aggressiveness: An Empirical Evidence
}

\author{
I Putu Abed Adi Pranata, Komang Adhitanaya, Muhammad Fairuz Rizaldi, \\ Gede Bramasta Eka Winanda, Ni Made Intan Dewi Lestari, Partiwi Dwi Astuti*
}

Faculty of Economics and Business, Warmadewa University, Denpasar, Indonesia

Received September 3, 2021; Revised October 12, 2021; Accepted November 11, 2021

\section{Cite This Paper in the following Citation Styles}

(a): [1] I Putu Abed Adi Pranata, Komang Adhitanaya, Muhammad Fairuz Rizaldi, Gede Bramasta Eka Winanda, Ni Made Intan Dewi Lestari, Partiwi Dwi Astuti, "The Effect of Corporate Social Responsibility, Firm Size, and Leverage on Tax Aggressiveness: An Empirical Evidence," Universal Journal of Accounting and Finance, Vol. 9, No. 6, pp. 1478-1486, 2021. DOI: 10.13189/ujaf.2021.090624.

(b): I Putu Abed Adi Pranata, Komang Adhitanaya, Muhammad Fairuz Rizaldi, Gede Bramasta Eka Winanda, Ni Made Intan Dewi Lestari, Partiwi Dwi Astuti (2021). The Effect of Corporate Social Responsibility, Firm Size, and Leverage on Tax Aggressiveness: An Empirical Evidence. Universal Journal of Accounting and Finance, 9(6), 1478-1486. DOI: 10.13189/ujaf.2021.090624.

Copyright $\mathrm{C} 2021$ by authors, all rights reserved. Authors agree that this article remains permanently open access under the terms of the Creative Commons Attribution License 4.0 International License

\begin{abstract}
Tax aggressiveness is an interesting research topic in the accounting and management literature. Tax aggressiveness is one of the driving factors in many corporate decisions. Research testing the link between CSR and firm size, leverage to tax aggressiveness is limited and shows inconsistent results. The study aims to test the influence of corporate social responsibility (CSR), firm size, and leverage on tax aggressiveness. The research was conducted in food and beverage sub-sector manufacturing companies listed on the Indonesia Stock Exchange for the period 2017-2019. A sample of 16 companies was determined using the purposive sampling technique. Data in the form of 48 financial statements obtained from the Indonesia Stock Exchange website. The data is analyzed using multiple linear regression analysis techniques, with SPSS 20 software. The results showed that CSR has no significant negative effect on tax aggressiveness; firm size has a significant positive effect on tax aggressiveness; and leverage has a significant negative effect on tax aggressiveness. The results of this study contribute to the financial accounting and taxation literature, especially the discussion of tax aggressiveness and the factors that influence it. Theoretically, the results of this study strengthen stakeholder theory and legitimacy theory. While practically, the results of this study can provide
\end{abstract}

understanding for companies about the factors that can affect tax aggressiveness.

Keywords Corporate Social Responsibility, Firm Size, Leverage, Tax Aggressiveness

\section{Introduction}

Tax aggressiveness is an action in an effort to reduce the tax burden imposed on companies through tax planning in the form of legal (tax avoidance), illegal (tax sheltering) or both [1]. Corporate tax aggressiveness is also assessed by how much companies take tax avoidance steps by utilizing gap in tax regulations that result in the non-achievement of the state's goal to maximize state revenues from the tax sector [2].

Companies engaged in corporate social responsibility (CSR) activities are less likely to take overtly aggressive tax actions [3]. CSR is a company's commitment to improve the welfare of the surrounding community through business practice policies and the contribution of corporate resources [4]. From the point of view of legitimacy theory and stakeholder theory, in order to 
implement CSR and gain community legitimacy, companies must reduce aggressive taxes [5]. The results of [6], [7], [8], and [3] showed that CSR negatively affects tax aggressiveness. Different results were shown by [9] and [10] which found CSR to have a positive effect on tax aggressiveness.

Firm size becomes another factor that affects tax aggressiveness. The larger the size of the company, the more the company will become the centre of government attention to be subject to appropriate taxes, so that the company will behave obediently or aggressive (tax avoidance) in taxation [11]. According to [12] tax aggressiveness can occur because large companies have more room for tax planning with the aim of lowering the effective tax rate (ETR). [13], [14], [6], [12], [15], [3], and [16] found that the size of the company had a significant positive effect on tax aggressiveness. This indicates that the larger firm size, the tax policy more aggressive. However, different results were shown by [10] and [8] that firm size has no effect on tax aggressiveness.

In the study of corporate characteristics and tax avoidance, leverage became another important variable. Leverage indicates the extent to which a company is financed by external or external funds that incur liabilities [17]. Interest payments on debts are tax deductible, so leverage serves as a tax shield for the company. A high leverage ratio indicates high funding used by the company from debt, which results in an increase in interest costs from the debt - higher interest costs will have an impact on reducing the company's tax burden [18]. The results of research conducted by [8] and [19] prove that leverage has a significant positive effect on tax aggressiveness, although [10] shows the opposite result, namely leverage does not have a significant effect on tax aggressiveness.

Although CSR and corporate tax aggressiveness are topics that have attracted a lot of attention in the academic literature (such as [20], [21], [22]), however, research that tests the linkage of CSR with tax aggressiveness is still limited [23]. Similarly, the linkage between firm size and leverage with tax aggressiveness is still rarely tested. Some studies that test the relationship between CSR, firm size, and leverage to tax aggressiveness as outlined above also still show gaps in research findings.

This research examines the influence of CSR, firm size, and leverage on tax aggressiveness, which is carried out in food and beverage sub-sector manufacturing companies listed on the Indonesia Stock Exchange for the period 2017-2019. The difference between this study and the previous study was that previous research only tested a portion of the variables tested in the study, whereas the study comprehensively tested several variables (CSR, firm size, and leverage) that could affect tax aggressiveness.

This research has a priority because: (1) taxes are a driving factor in many corporate decisions. (2) research that examines the linkage between CSR, firm size, and leverage against tax aggressiveness is limited; and (3) there are inconsistencies in the results of CSR influence research, firm size, and leverage on tax aggressiveness. The results of this study contribute to the financial accounting and taxation literature, especially the discussion of tax aggressiveness and the factors that affect it.

\section{Literature Review and Hypotheses}

\subsection{Review of the Theory Underlying Research}

During this time, the company was viewed using the assumption of agency theory, so CSR is considered to have little relevance to the company's operations [24]. According to agency theory [25], the most important relationship is between managers and shareholders, so that the company's activities outside that domain have little relevance and are counterproductive, because it does not maximize the company's profits [26].

In practice, there are business organizations that start their social activities based on direct interaction with stakeholders. However, there are also other business organizations that carry out similar activities to manage their level of social legitimacy. Therefore, two theories are influential in social and environmental accounting research, namely stakeholder theory and legitimacy theory. [27] suggest that legitimacy theory focuses on the suitability of an organization's value system to society's value system, and the fulfilment of social expectations of organizational goals. Meanwhile, stakeholder theory focuses on the relationship between organizations and the various stakeholders that make up the environment.

If a company is viewed using the assumption of stakeholder theory and legitimacy theory, then the company is seen as having a significant influence that exceeds its shareholders [3]. Globalization has demanded business organizations to be able to adapt quickly to environmental changes. In order to achieve competitive advantage, it is necessary to analyse the competitive environment, choose a strategy, and have adequate resources [28]. In such circumstances, the company's policies, strategies and operations will not be solely shareholder-centered, but will take into account other stakeholders (e.g., governments, political groups, unions, communities, employees, suppliers and customers) and members of the public as a whole [3].

Legitimacy theory and stakeholders have a relationship. In order for a company to gain support for its survival, managers must understand the needs and interests of stakeholder groups [27]. Companies seek to legitimize and maintain corporate relationships in the broader social and political environment in which companies operate and that without such legitimacy, companies would not survive [29] - CSR emphasizes legitimate stakeholder engagement, due to the fact that corporate profitability demands a 
responsible strategy that reflects social concerns [30]. Companies must be aware that the goal of social responsibility in organizational strategy is not only driven by the desire to build a positive image, operational efficiency or the achievement of competitive advantage, but is also a condition for building a sustainable business [31]. Aggressive tax policies by corporations can have a negative impact on the society and can be perceived as socially irresponsible, negating previous CSR performance [32]. Socially responsible companies will reduce tax aggressiveness, because tax aggressiveness can damage the company's reputation [21].

\subsection{Tax Aggressiveness, CSR, Firm Size, Leverage}

Tax aggressiveness is an effort by companies to minimize tax payments by using aggressive tax planning activities and tax avoidance [19]. This is similar to the definition of [33] that tax aggressiveness is an attempt by management to reduce taxable income through tax planning activities legally, illegally, and among other (grey areas). [34] suggest tax aggressiveness activities are characterized by complexity and obscurity, which are practically difficult to detect.

CSR is defined as the way businesses take into account the social and environmental impact of operating, maximizing benefits and minimizing losses [3]. CSR is the ongoing commitment of a business to behave ethically and contribute to economic development and improve the quality of life of its workforce as well as local communities and the wider community [35], in accordance with values and norms [36].

The smallness of a company can affect taxes in several ways, namely the nature of tax aggressiveness and tax reduction [37]. The advantages of large corporations that have economic and political power make large companies more vulnerable to aggressive tax avoidance [38]. This is in line with the political cost hypothesis in positive accounting theory that reveals companies will tend to use accounting methods that can reduce revenue in the current period to minimize political costs such as tax burdens [17].

A company's policy in financing activities through the use of debt to finance corporate activities is referred to as leverage [39]. Leverage is the ratio to indicate the level of debt used by the company [40]. The amount of interest expense will affect the amount of corporate tax burden [41].

\subsection{Hypotheses Formulation}

Taking the view point that a company is a "real-world" entity with all its social obligations, and corporate taxation impacts society through CSR, it must pay its fair share of taxes levied legally by governments wherever the company operates [20] - in order to ensure its survival, the company must obtain legitimacy and support from every stakeholder. Although it costs a lot of money, the implementation of CSR can be a way to gain such legitimacy and support. Obtaining legitimacy and support from stakeholders, will have a positive impact on the company's image and reputation because the company is considered socially responsible. Socially responsible companies have incentives to maintain their good image and reputation [21].

Paying a fair share of taxes is an important component of CSR that helps maintain a company's image and reputation. CSR can be used by companies to divert attention from unwanted tax planning activities [36]. Therefore, to increase the company's CSR activities, a reduction in tax aggressiveness is needed. Socially responsible companies can reduce tax aggressiveness because CSR is a legitimate business activity and not just a cost to maximize shareholder wealth [20]. Giving a positive picture needs to be done by companies to build legitimacy. It is difficult to find a company that admits that it has practiced tax aggressiveness, because it can damage its social status and legitimacy [42]. [6], [7], [8], and [3] showed that CSR negatively affects tax aggressiveness.

\section{H1: CSR has a negative effect on tax aggressiveness}

Proponents of the 'political cost hypothesis' claim that large corporations are not only subject to government scrutiny. However, it also transfers more wealth than small companies. Therefore, this makes the tax burden of large companies higher than small companies [43]. [44] reveals that large corporations tend to have good tax planning and adopt effective accounting practices to lower ETR. A low ETR can indicate tax aggressiveness [45]. [13], [14], [6], [12], [15], [3], and [16] found the size of the company to have a positive effect on tax aggressiveness.

\section{H2: Firm size has a positive effect on tax aggressiveness}

Trade-off theory reveals that companies tend to take advantage of debt to minimize tax burden [46]. [47] argued that when a company relies more on financing from debt than equity for operations, it will have a lower ETR. This is because the reduction in corporate income tax as a result of paying interest on debt will reduce the cost of financing with debt compared to other types of financing [48]. Companies with high levels of leverage have more ability to avoid taxes through financial transactions [46]. Therefore, there is a positive relationship between corporate leverage and tax aggressiveness [8], [19].

\section{H3: Leverage has a positive effect on tax aggressiveness.}

Based on the formulation of the hypothesis above, the conceptual model of this research can be described in Figure 1. 


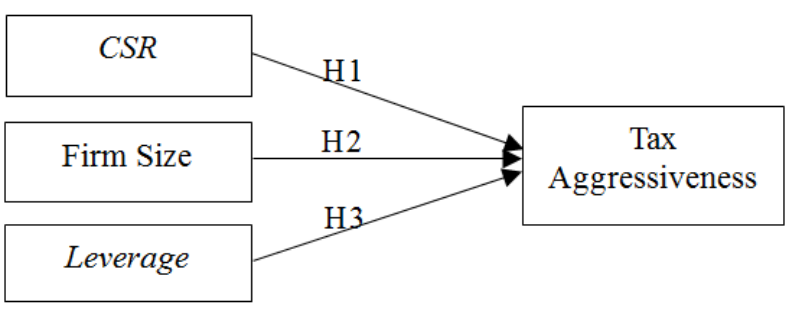

Figure 1. Conceptual Framework

\section{Methods}

\subsection{Population and Sampling Method}

The population in this study was all food and beverage companies registered with the Indonesia Stock Exchange in the period 2017-2019 which amounted to 28 companies. The sample is determined by purposive sampling technique, with criteria: 1). The company is registered with the Indonesia Stock Exchange during the period 2017-2019; 2). No loss during the period 2017-2019; 3). Have complete data; and 4). It doesn't have extreme data. Based on these criteria, the sample size of this study was 16 companies.

\subsection{Variable Measurement}

CSR is measured by the Corporate Social Responsibility Index (CSRI) guided by the fourth generation GRI with 91 CSR disclosure indexes.

$$
\text { CSRI } i=\frac{\sum x y i}{n i}
$$

CSRIi is the broad index of corporate CSR disclosure $\mathrm{i}$; $\sum$ Xyi with a value of 1 if item y is disclosed, value 0 if item y is not disclosed; this is the number of items company i with ni $\leq 91$.

Firm size is measured using the natural logarithm of total assets, as follows:

$$
\text { Firm Size }=\text { Ln (total aset })
$$

Leverage is a ratio measured by comparing long-term debt with its total assets.

$$
\text { Leverage }=\frac{\text { Non-Current Liabilities }}{\text { Total assets }}
$$

Tax aggressiveness is measured through effective tax rate (ETR).

$$
E T R=\frac{\text { Tax Expenses }}{\text { Total Profit Before Tax }}
$$

\subsection{Data Collection and Analysis Techniques}

Data is collected using documentation methods. Documents collected in the form of financial statements of food and beverage companies registered with the Indonesia Stock Exchange for the period 2017-2019. With a sample of 16 companies and 3 years of reporting, the data collected as many as 48 financial statements.

The data is analyzed with descriptive statistics to give an overview of the research variables. Classical assumption tests are performed by performing tests of normality, multicollinearity, autocorrelation, and heteroscedasticity. The hypothesis test is conducted using multiple linear regression techniques, with equations:

$$
Y=\alpha+\beta_{1} X_{1}+\beta_{2} X_{2}+\beta_{3} X_{3}+e
$$

$\mathrm{Y}=$ tax aggressiveness; $\alpha=$ constant; $\beta_{1}-\beta_{3}=$ regression coefficient; $\mathrm{X}_{1}=C S R ; \mathrm{X}_{2}=$ firm size; $\mathrm{X}_{3}=$ leverage; $e=$ standard error. SPSS 20 software is used to help analyze this research data.

\section{Results}

\subsection{Descriptive Statistics}

An overview of the research variables is shown in Table 1. Table 1 shows that the broad index of CSR disclosures in sample companies ranges from 0.253 to 0.780 ; with an average value of 0.517 . Sample firm size indicated by natural logarithms of the lowest assets 27.081 and the highest 32.201; with an average score of 28.871 . This study sample has leverage of 0.016 to 0.505 ; with an average 0.150 . While the aggressiveness of the sample corporate tax shown by the ETR is at least 0.161 and highest 0.334 , with an average of 0.256 mean values greater than the standard deviation indicate that the mean value is a good representation of the entire data.

Table 1. Descriptive Statistics

\begin{tabular}{|c|c|c|c|c|c|}
\hline & $\mathbf{N}$ & Minimum & Maximum & Mean & Std. Deviation \\
\hline CSR & 48 & .253 & .780 & .51671 & .153637 \\
\hline Firm Size & 48 & 27.081 & 32.201 & 28.87064 & 1.463882 \\
\hline Leverage & 48 & .016 & .505 & .15001 & .116758 \\
\hline Tax Aggressiveness & 48 & .161 & .334 & .25613 & .036435 \\
\hline Valid N (listwise) & 48 & & & & \\
\hline
\end{tabular}




\subsection{Classical Assumption Test}

Table 2. Normality Test Results

\begin{tabular}{|c|c|c|}
\hline & & $\begin{array}{c}\text { Unstandardized } \\
\text { Residual } \\
\end{array}$ \\
\hline \multicolumn{2}{|l|}{$\mathbf{N}$} & 48 \\
\hline \multirow{2}{*}{ Normal Parameters ${ }^{\mathrm{a}, \mathrm{b}}$} & Mean & .0000000 \\
\hline & Std. Deviation & .02569116 \\
\hline \multirow{3}{*}{ Most Extreme Differences } & Absolute & .053 \\
\hline & Positive & .044 \\
\hline & Negative & -.053 \\
\hline \multicolumn{2}{|l|}{ Test Statistic } & .053 \\
\hline \multicolumn{2}{|c|}{ Asymp. Sig. (2-tailed) } & $.200^{\mathrm{c}, \mathrm{d}}$ \\
\hline
\end{tabular}

The results of the normality test using one-sample
Kolmogorov Smirnov are shown in Table 2. Significance values (Asymp Sig) $0.200>0.05$, so it is concluded that residual data is distributed normally.

Multicollinearity test results are seen from tolerance and variance inflation factor (VIF) values in Table 3. The table shows that no independent variable has a tolerance value of less than 0.10 and a VIF value of more than 10 . This shows that there is no correlation between independent variables whose value is more than $95 \%$. Therefore, it is concluded that there is no multicollinearity between independent variables in the regression model.

Table 4 shows the results of the autocorrelation test with the run test. The test on Table 4 of 0.00132 with a probability of 0.189 is insignificant at 0.05 , so it is concluded that residual random or no autocorrelation occurs between residual values.

Table 3. Multicolinearity Test Result

\begin{tabular}{|c|c|c|c|c|c|c|c|c|}
\hline & \multirow{2}{*}{ Model } & \multicolumn{2}{|c|}{ Unstandardized Coefficients } & \multirow{2}{*}{$\begin{array}{c}\begin{array}{c}\text { Standardized } \\
\text { Coefficients }\end{array} \\
\text { Beta }\end{array}$} & \multirow{2}{*}{ t } & \multirow{2}{*}{ Sig. } & \multicolumn{2}{|c|}{ Collinearity Statistics } \\
\hline & & B & Std. Error & & & & Tolerance & VIF \\
\hline \multirow{4}{*}{1} & (Constant) & -.340 & .100 & & -3.380 & .002 & & \\
\hline & CSR & -.043 & .036 & -.180 & -1.177 & .245 & .482 & 2.076 \\
\hline & Ukuran perusahaan & .022 & .004 & .876 & 5.521 & .000 & .449 & 2.229 \\
\hline & Leverage & -.079 & .035 & -.252 & -2.216 & .032 & .875 & 1.142 \\
\hline
\end{tabular}

Table 4. Autocorelation Test Results

\begin{tabular}{|c|c|}
\hline & Unstandardized Residual \\
\hline Test Value $^{\mathbf{a}}$ & .00132 \\
\hline Cases $\boldsymbol{<}$ Test Value & 24 \\
\hline Cases $>$ = Test Value & 24 \\
\hline Total Cases & 48 \\
\hline Number of Runs & 20 \\
\hline $\mathbf{Z}$ & -1.313 \\
\hline Asymp. Sig. (2-tailed) & .189 \\
\hline
\end{tabular}

Heteroscedasticity test results using scatterplots graph shown in Figure 2. 


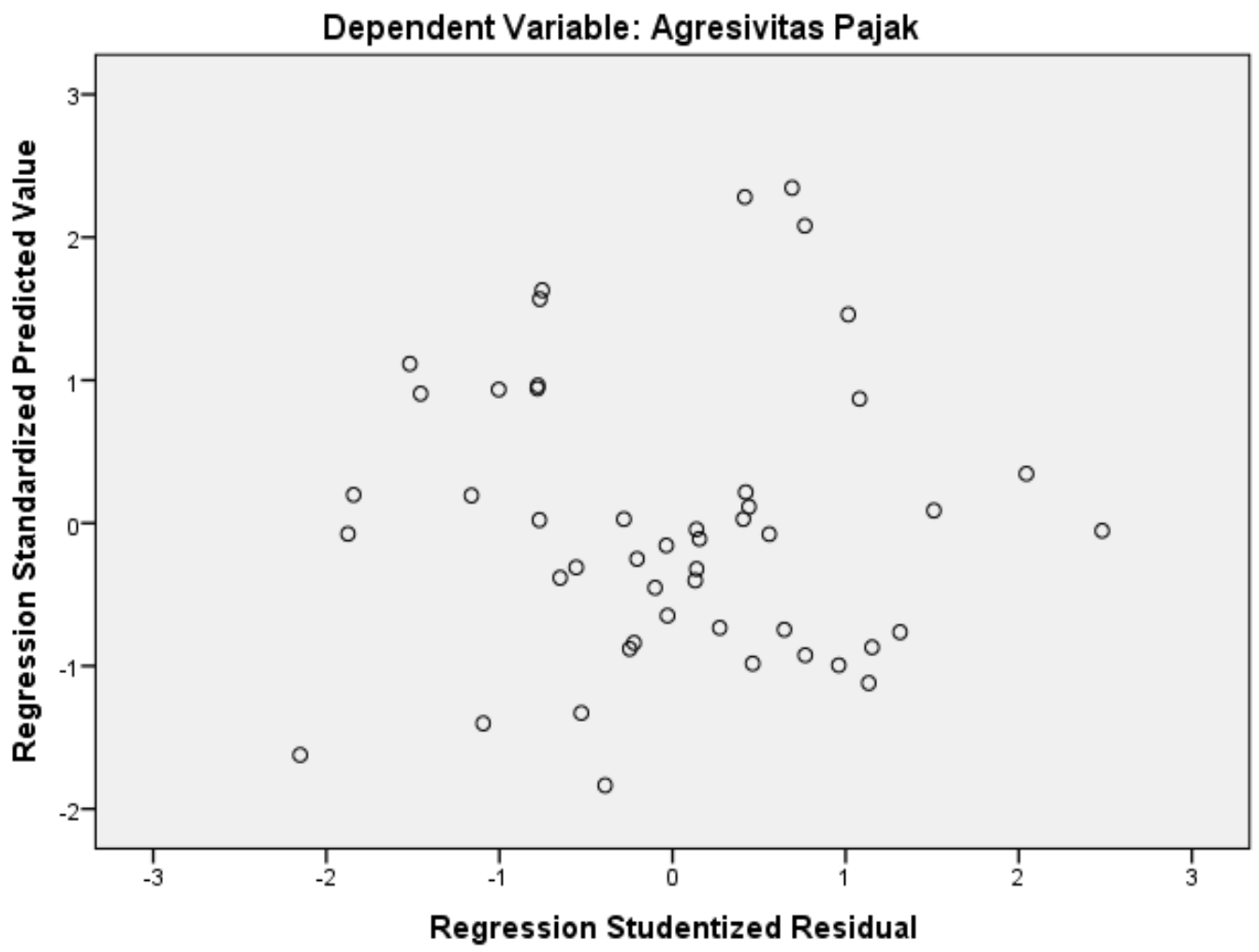

Figure 2. Heteroscedasticity Test Results

The duck-dots in the scatterplot graph spread randomly, spread both above and below the number 0 on the $\mathrm{Y}$ axis, it can be concluded that there is no heteroscedasticity in regression models.

\subsection{Hypotheses Test}

Hypothesis test results using multiple linear regression analysis techniques are shown in Table 5.

Table 5. Individual Parameter Significance Test Results ( $\mathrm{t}$ Test)

\begin{tabular}{|c|c|c|c|c|c|c|}
\hline & \multirow{2}{*}{ Model } & \multicolumn{2}{|c|}{ Unstandardized Coefficients } & \multirow{2}{*}{$\begin{array}{c}\begin{array}{c}\text { Standardized } \\
\text { Coefficients }\end{array} \\
\text { Beta }\end{array}$} & \multirow[t]{2}{*}{$\mathbf{t}$} & \multirow[t]{2}{*}{ Sig. } \\
\hline & & B & Std. Error & & & \\
\hline \multirow{4}{*}{1} & (Constant) & -.340 & .100 & & -3.380 & .002 \\
\hline & CSR & -.043 & .036 & -.180 & -1.177 & .245 \\
\hline & Firm Size & .022 & .004 & .876 & 5.521 & .000 \\
\hline & Leverage & -.079 & .035 & -.252 & -2.216 & .032 \\
\hline
\end{tabular}

Basing Table 5 obtained the following mathematical equations.

$$
Y=-0,340-0.043 X_{1}+0.022 X_{2}-0.079 X_{3}
$$

Results of model feasibility test using $\mathrm{F}$ test shown in Table 6.

Table 6. Simultaneous Significance Test Results (Test F)

\begin{tabular}{|c|c|c|c|c|c|c|}
\hline \multicolumn{2}{|c|}{ Model } & Sum of Squares & df & Mean Square & F & Sig. \\
\hline \multirow{3}{*}{1} & Regression & .031 & 3 & .010 & 14.832 & $.000^{\mathrm{b}}$ \\
\cline { 2 - 7 } & Residual & .031 & 44 & .001 & & \\
\cline { 2 - 7 } & Total & .062 & 47 & & & \\
\hline
\end{tabular}


Table 7. $\mathrm{R}^{2}$ Test Results

\begin{tabular}{|c|c|c|c|c|c|}
\hline Model & R & R Square & Adjusted R Square & Std. Error of the Estimate & Durbin-Watson \\
\hline 1 & $.709^{\mathrm{a}}$ & .503 & .469 & .026553 & 1.361 \\
\hline
\end{tabular}

a. Predictors: (Constant), Leverage, CSR, Firm Size

b. Dependent Variable: Tax Aggressiveness

F count 14.843 with a probability of $0.000<0.05$, so regression models can be used to predict tax aggressiveness (decent models). In other words, CSR, firm size, and leverage simultaneously affect tax aggressiveness.

The effect of individually independent variables on dependent variables can be demonstrated from the results of the individual parameter significance test (test $t$ ) in Table 5. CSR regression coefficient is -0.043 , with a significance level of $0.245>0.05$, which means that CSR has an insignificant negative effect on tax aggressiveness. Therefore the first hypothesis that states CSR has a negative effect on tax aggressiveness is rejected.

Table 5 shows the regression coefficient value of firm size of 0.022 with a significance level of $0.000<0.05$, which means firm size has a significant positive effect on tax aggressiveness. Therefore the second hypothesis that states firm size has a positive effect on tax aggressiveness is accepted.

The results of the individual parameter significance test for leverage show that the variable has a regression coefficient of -0.079 with a significance level of $0.032<0.05$, which means that leverage has a significant negative effect on tax aggressiveness. Therefore the third hypothesis that states leverage has a positive effect on tax aggressiveness is rejected.

Measurement of how far the model's ability to explain the variation of dependent variables is done by looking at the value of the coefficient of determination, shown in Table 7. Adjusted R Square is worth 0.469 , which means that $46.9 \%$ variation in tax aggressiveness can be explained by variations of all three independent variables (CSR, firm size, leverage). The remaining $53.1 \%$ $(100 \%-46.9 \%)$ is explained by other reasons outside the model.

\section{Discussions}

The discovery of an insignificant negative influence of CSR on tax aggressiveness in food and beverage companies listed on the Indonesia Stock Exchange for the period 2017-2019 shows that the wider CSR disclosures made by these companies, have not been able to significantly reduce tax aggressiveness companies involved in CSR may be less aggressive towards taxes due to the need to deliver transparency, integrity, and a good reputation [32]. According to [49] insignificant negative influences can also occur as a result of the not disclosed of all CSR activities, so that not all costs for such activities are presented in the financial statements. This causes profits not to decrease drastically, and taxes paid do not increase sharply. The results of this hypothesis test are in line with [36], [50], [49], and [13], that CSR has a negative effect is not significant on tax aggressiveness. These findings prove that claims to engage in CSR can hide many inconsistencies in a company's approach to CSR [51]. In addition, social responsibility behavior, is not always in line with the company's actions in terms of paying its share of taxes [42].

Firm size that has a significant positive effect on the tax aggressiveness of food and beverage companies listed on the Indonesia Stock Exchange for the 2017-2019 period shows that the larger firm size, the more aggressive the tax is. This can be explained from the point of view of political power theory. According to the theory, larger companies have lower ETRs, as they have substantial resources available to companies to manipulate favourable political processes, engage in tax planning, and organize corporate activities to achieve optimal tax savings [52]. Large corporations tend to be more tax aggressive than small companies because large corporations have greater economic and political power compared to smaller companies [49]. This makes large companies better able to reduce their tax burden [3]. This finding is consistent with the political cost hypothesis which suggests that greater visibility of larger firms exposes them to greater regulatory action [15]. The study's findings support [13], [14], [6], [12], [15], [3], and [16] who found firm size to have a significant positive effect on tax aggressiveness.

Significant negative leverage against tax aggressiveness indicates that the high leverage of food and beverage companies listed on the Indonesia Stock Exchange for the period 2017-2019 significantly decreases tax aggressiveness. Leverage is an external source of funding derived from debt. The number of external parties participating in the company's funding, increase supervision of the company's management [40]. The increased scrutiny decreases the motivation of companies to commit tax aggressiveness. These findings support [40], [53], [11], and [16] which show a significant negative influence of leverage on tax aggressiveness.

\section{Conclusions}

The study examined the influence of CSR, firm size, and leverage on tax aggressiveness. The results showed that firm size and leverage have an influence on tax aggressiveness. The study also proved that CSR has no 
significant influence on tax aggressiveness.

This research has limitations because it is only conducted in food and beverage sub-sector manufacturing companies listed on the Indonesia Stock Exchange for the period 2017-2019, thus reducing the generalization of the findings of this study. Further research may be conducted in broader subjects, for example in other sub-sector companies, or in non-manufacturing companies. Further research can also be done by testing other variables not tested in this study, which may affect tax aggressiveness, for example profitability, capital intensity, return on asset, independent commissioner, or liquidity.

\section{Acknowledgments}

We would like to present our gratitude of the Ministry of Education, Culture, Research and Technology of the Republic of Indonesia and Warmadewa University.

\section{REFERENCES}

[1] P. M. Prasista and E. Setiawan, "Pengaruh profitabilitas dan pengungkapan corporate social responsibility terhadap agresivitas pajak penghasilan wajib pajak badan," E-Jurnal Akunt. Univ. Udayana, vol. 17, no. 3, pp. 2120-2144, 2016.

[2] A. Putri, A. Rohman, and A. Chariri, "Tax avoidance, earnings management, and corporate governance mechanism (an evidence from Indonesia)," Int. J. Econ. Res., vol. 13, no. 4, pp. 1931-1943, 2016.

[3] R. Lanis and G. Richardson, "Corporate social responsibility and tax aggressiveness: an empirical analysis," J. Account. Public Policy, vol. 31, no. 1, pp. 86-108, 2012.

[4] F. Perrini, "Corporate social responsibility: doing the most good for your company and your cause," Acad. Manag. Perspect., vol. 20, no. 2, pp. 90-93, 2006.

[5] R. Lanis and G. Richardson, "The effect of board of director composition on corporate tax aggressiveness," J. Account. Public Policy, vol. 30, no. 1, pp. 50-70, 2011.

[6] H. L. Kuriah and N. F. Asyik, "Pengaruh karakteristik perusahaan dan corporate social responsibility terhadap agresivitas pajak," J. Ilmu dan Ris. Akunt., vol. 5, no. 3, pp. $1-19,2016$.

[7] T. Zeng, "Corporate social responsibility, tax aggressiveness, and firm market value," Account. Perspect., vol. 15, no. 1, pp. 7-30, 2016.

[8] N. B. Nugraha, "Pengaruh corporate social responsibility, ukuran perusahaan, profitabilitas, leverage dan capital intensity terhadap agresifitas pajak," Universitas Diponegoro, 2015.

[9] L. L. Oktaviana and Wahidahwati, "Pengaruh kepemilikan saham dan corporate social responsibility terhadap agresivitas pajak," J. Ilmu dan Ris. Akunt., vol. 6, no. 11, pp. $1-20,2017$.
[10] Mustika, "Pengaruh corporate social responsibility, ukuran perusahaan, profitabilitas, leverage, capital intensity, dan kepemilikan keluarga terhadap agresivitas pajak," JOM Fekom, vol. 4, no. 1, pp. 1886-1900, 2017.

[11] T. Kurniasih and M. M. R. Sari, "Pengaruh return on assets, leverage, corporate governance, ukuran perusahaan dan kompensasi rugi fiskal pada tax avoidance," Bul. Stud. Ekon., vol. 18, no. 1, pp. 58-66, 2013.

[12] D. Ardyansah, "Pengaruh size, leverage, profitability, capital intensity ratio dan komisaris independen terhadap effective tax rate (ETR)," Universitas Diponegoro, 2014.

[13] J. Kim and C. Im, "Study on corporate social responsibility (CSR): focus on tax avoidance and financial ratio analysis," Sustainability, vol. 9, no. 10, pp. 1-15, 2017.

[14] D. Sari and C. Tjen, "Corporate social responsibility disclosure, environmental performance, and tax aggressiveness," Int. Res. J. Bus. Stud., vol. IX, no. 2, pp. 93-104, 2016.

[15] E. Fernández-Rodríguez and A. Martínez-Arias, "Determinants of the effective tax rate in the BRIC countries," Emerg. Mark. Financ. Trade, vol. 50, no. Supplement 3, pp. 214-228, 2014.

[16] R. M. Noor, N. S. M. Fadzillah, and N. Mastuki, "Corporate tax planning: a study on corporate effective tax rates of Malaysian listed companies," Int. J. Trade, Econ. Financ., vol. 1, no. 2, pp. 189-193, 2010.

[17] K. A. Yahaya and K. Yusuf, "Impact of company characteristics on aggressive tax avoidance in Nigerian listed insurance companies," J. Adm. Bisnis, vol. 9, no. 2, pp. 101-111, 2020.

[18] L. Wahyuni, R. Fahada, and B. Atmaja, "The effect of business strategy, leverage, profitability and sales growth on tax avoidance," Indones. Manag. Account. Res., vol. 16, no. 2, pp. 66-80, 2017.

[19] S. Chen, X. Chen, Q. Cheng, and T. Shevlin, "Are family firms more tax aggressive than non-family firms?," $J$. financ. econ., vol. 9, no. 1, pp. 41-61, 2010.

[20] R. Lanis and G. Richardson, "Is corporate social responsibility performance associated with tax avoidance?," J. Bus. Ethics, vol. 127, no. 2, pp. 439-457, 2015.

[21] S. Landry, M. Deslandes, and A. Fortin, "Tax aggressiveness, corporate social responsibility, and ownership structure," J. Accounting, Ethics Public Policy, vol. 14, no. 3, pp. 611-645, 2013.

[22] M. Hanlon and S. Heitzman, "A review of tax research," $J$. Account. Econ., vol. 50, no. 2-3, pp. 127-178, 2010.

[23] F. Karundeng and V. A. Upa, "Analysis the effect of corporate social responsibility on tax avoidance with profitability and firm size as moderating variables," Int. J. Soc. Syst. Sci., vol. 12, no. 3, pp. 215-230, 2020.

[24] R. L. Watts and J. L. Zimmerman, "Positive accounting theory: a ten year perspective," Account. Rev., vol. 65, no. 1, pp. 131-156, 1990.

[25] E. F. Fama and M. C. Jensen, "Separation of ownership and control," J. Law Econ., vol. 26, no. 2, pp. 301-325, 1983. 
[26] M. Friedman, Capitalism and freedom. Chicago: The University of Chicago Press, 2002.

[27] J. C. Chen and R. W. Roberts, "Toward a more coherent understanding of the organization-society relationship: a theoretical consideration for social and environmental accounting research," J. Bus. Ethics, vol. 97, no. 4, pp. 651665,2010

[28] Y. F. T. Jaya, M. Nasir, and P. Dewi, "The impact of external environment on competitive advantage through SME differentiation strategy in Central Java," Univers. $J$ Manag., vol. 9, no. 2, pp. 38-43, 2021.

[29] R. Gray, R. Kouhy, and S. Lavers, "Corporate social and environmental reporting. A review of the literature and a longitudinal study of UK disclosure," Accounting, Audit. Account. J., vol. 8, no. 2, pp. 47-77, 1995.

[30] E. Weisband, "The virtues of virtue: social capital, network governance, and corporate social responsibility," $\mathrm{Am}$. Behav. Sci., vol. 52, no. 6, pp. 905-918, 2009.

[31] M. C. Ganescu, "Corporate social responsibility, a strategy to create and consolidate sustainable businesses," Theor. Appl. Econ., vol. XIX, no. 11(576), pp. 91-106, 2012.

[32] C. Mgbame, M. Chijoke-Mgbame, S. Yekini, and Y. C. Kemi, "Corporate social responsibility performance and tax aggressiveness," J. Account. Tax., vol. 9, no. 8, pp. 101-108, 2017.

[33] I. Laguir, R. Stagliano, and J. Elbaz, "Does corporate social responsibility affect corporate tax aggressiveness?," $J$. Clean. Prod., vol. 107, pp. 662-675, 2015.

[34] A. Boussaidi and M. S. Hamed, "The impact of governance mechanisms on tax aggressiveness: empirical evidence from Tunisian context," Asian Econ. Soc. Soc., vol. 5, no. 1, pp. 1-12, 2015.

[35] P. Žukauskas, J. Vveinhardt, and R. Andriukaitienè, Corporate social responsibility as the organization's commitment against stakeholders. London: IntechOpen, 2018.

[36] F. Kristiadi, E. P. Kurniawati, and A. M. Naufa, "Corporate social responsibility and tax aggressiveness: evidence from Indonesia," J. Theory Appl. Manag., vol. 13, no. 2, pp. 105121,2020 .

[37] S. Sugeng, E. Prasetyo, and B. Zaman, "Does capital intensity, inventory intensity, firm size, firm risk, and political connections affect tax aggressiveness?," JEMA J. Ilm. Bid. Akunt. dan Manaj., vol. 17, no. 1, pp. 78-87, 2020.

[38] C. K. Hoi, Q. Wu, and H. Zhang, "Is corporate social responsibility (CSR) associated with tax avoidance? Evidence from irresponsible CSR activities," Account. Rev., vol. 88, no. 6, pp. 2025-2059, 2013.

[39] Ngadiman and C. Puspitasari, "Pengaruh leverage, kepemilikan institusional, dan ukuran perusahaan terhadap penghindaran pajak (tax avoidance) pada perusahaan sektor manufaktur yang terdaftar di Bursa Efek Indonesia 2010-2012," J. Akunt., vol. XVIII, no. 3, pp. 408-421, 2014.

[40] M. Aprianto and S. Dwimulyani, "Pengaruh sales growth dan leverage terhadap tax avoidance dengan kepemilikan institusional sebagai variabel moderasi," in Seminar Nasional Pakar ke 2 Tahun 2019. Buku 2 Sosial dan Humaniora, 2019, pp. 1-10.

[41] Y. Susilowati, R. Widyawati, and Nuraini, "Pengaruh ukuran perusahaan, leverage, profitabilitas, capital intensity ratio dan komisaris independen terhadap effective tax rate," in Prosiding SENDI_U 2018, 2018, pp. 796-804.

[42] P. Sikka, "Smoke and mirrors: corporate social responsibility and tax avoidance-a reply to Hasseldine and Morris," Account. Forum, vol. 37, no. 1, pp. 15-28, 2013.

[43] M. M. Frank, L. J. Lynch, and S. O. Rego, "Tax reporting aggressiveness and its relation to aggressive financial reporting," Account. Rev., vol. 84, no. 2, pp. 467-496, 2009.

[44] E. Fernández-Rodríguez and A. Martínez-Arias, "Do business characteristics determine an effective tax rate?," Chinese Econ., vol. 45, no. 6, pp. 60-83, 2012.

[45] A. W. Leksono, S. S. Albertus, and R. Vhalery, "Pengaruh ukuran perusahaan dan profitabilitas terhadap agresivitas pajak pada perusahaan manufaktur yang listing di BEI periode tahun 2013-2017," J. Appl. Bus. Econ., vol. 5, no. 4, pp. 301-314, 2019.

[46] [46] A. L. Santini and E. Indrayani, "The effect of profitability, liquidity, leverage, capital intensity and firm size on tax aggressiveness with market performance as an intervening variable (banking companies listed on Indonesia Stock Exchange in 2014 - 2018)," J. Ilm. Ekon. Bisnis, vol. 25, no. 3, pp. 290-303, 2020.

[47] B. S. Irianto, Y. A. Sudibyo, and A. Wafirli, "The influence of profitability, leverage, firm size and capital intensity towards tax avoidance," Int. J. Account. Tax., vol. 5, no. 2, pp. 33-41, 2017.

[48] C. Badarau-Semenescu and A. Semenescu, "Fiscal policy and the cost of external finance to firms. Microeconomic and macroeconomic implications," Emerg. Mark. Financ. Trade, vol. 46, no. SUPPL. 1, pp. 36-50, 2010.

[49] Y. Harjito, C. N. Sari, and Yulianto, "Tax aggressiveness seen from company characteristics and corporate social responsibility," J. Audit. Financ. Forensic Account., vol. 5, no. 2, pp. 77-91, 2017.

[50] D. K. Wardani and R. Purwaningrum, "Pengaruh karakteristik perusahaan dan corporate social responsibility terhadap penghindaran pajak," J. Ris. Akunt. dan Keuang., vol. 14, no. 1, pp. 1-13, 2018.

[51] L. Preuss, "Tax avoidance and corporate social responsibility: you can't do both, or can you?," Corp. Gov., vol. 10, no. 4, pp. 365-374, 2010.

[52] G. Richardson and R. Lanis, "Determinants of the variability in corporate effective tax rates and tax reform: evidence from Australia," J. Account. Public Policy, vol. 26, no. 6, pp. 689-704, 2007.

[53] C. Swingly and I. M. Sukartha, "Pengaruh karakter eksekutif, komite audit, ukuran perusahaan, leverage, dan sales growth pada tax avoidance," E-Jurnal Akunt. Univ. Udayana, vol. 1, no. 1, pp. 47-62, 2015. 